\title{
Global Private Capital Flows and Development Finance in Sub-Saharan Africa: Exemplary Performers, Lessons for Others, and Strategies for Global Competitiveness in the Twenty-First Century
}

\author{
Ashford C. Chea, $\mathrm{PhD}$ \\ School of Business, Kentucky Wesleyan College \\ 4721 Covert Avenue, Evansville, IN 47714 USA
}

Tel: 812-471-9341Ｅ-mail: achea@ix.netcom.com

Received: August 13, 2011

Accepted: September 15, 2011

doi:10.5539/jsd.v4n5p18

\begin{abstract}
Abundant global liquidity combined with improved economic policies and prospects in many SSA countries led to a surge in private capital flows, with sharp increases in all forms of private capital flows-FDI, portfolio investment, private debt flows - to SSA. As a result, in 2007 for the first time ever, private capital flows increased almost six-fold since 2000 to reach an estimated \$84bn, double the amount of ODA to SSA. However, the onset of the financial crisis radically changed the picture, with a drying up and, in some cases such as South Africa, a large reversal of capital flowsThe author begins the paper with a brief historical perspective of global capital flows to Sub-Saharan Africa (SSA). He then presents the methodology employed during the research. This is followed by the review of the literature. Next, the researcher outlines the theoretical framework of the paper and his findings. He also analyzes economic strategies to attract global capital and policy implications for decision makers of SSA economies. The author ends the paper with some policy recommendations and the way forward for SSA. The purpose of this paper is to exam why some SSA economies do attract more global private capital flows than others and what lessons can be learned from the best performers. This investigation is done through the review of relevant literature, analysis of empirical research, and policy implications and recommendations in this paper.
\end{abstract}

Keywords: Global, Private, Capital, Flows, Sub-Saharan Africa

\section{Introduction}

For decades, SSA had been heavily dependent on official development assistance (ODA) to finance persistent balance of payments deficit. With low income and generally weak economic policies, most countries in SSA were unattractive to private investors, and thus received little private capital, except for foreign direct investment (FDI) in sectors focused on natural resources extraction. This has changed in the last decade. Abundant global liquidity combined with improved economic policies and prospects in many SSA countries led to a surge in private capital flows, with sharp increases in all forms of private capital flows-FDI, portfolio investment, private debt flows - to SSA. As a result, in 2007 for the first time ever, private capital flows increased almost six-fold since 2000 to reach an estimated $\$ 84 \mathrm{bn}$, double the amount of ODA to SSA. The onset of the financial crisis radically changed the picture, with a drying up and, in some cases such as South Africa, a large reversal of capital flows (Delechat et al, 2009).

\subsection{Attractiveness of SSA forInvestment}

Abundant Natural Resources-Many SSA countries are endowed with rich and relatively untouched natural resources, which usually offer a high rate of return on FDI. This is the case for Chinese investments such as in Angola (oil), DRC (Copper and cobalt), Liberia (iron ore), and Sudan (oil).

Improving investment and Business Climate-Several SSA countries, such as Zambia and Ghana have recently introduced business facilitation measures and reformed legal frameworks for FDI. This has created an enabling environment that is attracting investment outside of the natural resource sector.

Better Macroeconomic Conditions-SSA countries have achieved relatively stable macroeconomic conditions with lower inflation and better fiscal and external balances. Countries with strong fiscal positions such as Botswana have attracted the establishment of major Chinese construction companies which are interested in bidding for government contracts (Rogoff and Reinhart, 2003). 
Greater Economic Liberalization and Deregulation-Many SSA countries have pursued economic liberalization and deregulation for the past few years, giving foreign firms a better access to their markets, e.g., in Ethiopia.

Privatization-Many SSA countries have been privatizing state-owned enterprises to reduce the burden on the budget and make the enterprises more efficient. Privatization has attracted FDI as a relatively easy access to SSA markets for foreign investors, for example, in Zambia, a large number of assets in the mining sector acquired by foreign companies used to be state-owned.

Preferential Trade Schemes-The EU's Everything but Arms (EBA) program and the U.S. African Growth and Opportunity Act (AGOA) have given foreign firms more incentive to invest in SSA countries as a base for exporting to Europe and the US, especially in sectors such apparel where low-cost are a key consideration (Mlachila and Takebe, 2011).

\subsection{The Problem of Significant Heterogeneity of Growth and Global Private Capital Flows within SSA}

Even though overall in SSA remains strong, there is significant heterogeneity across sub-regions in terms of the distribution of growth and capital inflows. Across sub-regions, growth was strongest in West Africa (6.5 percent) powered by Nigeria's robust growth (7.9 percent) and supported by Ghana's 7.7 percent gains in the year. GDP growth in East Africa was almost as strong, with Ethiopia (7 percent), Rwanda ( 7.5 percent), Tanzania ( 7 percent) and Kenya (5.6 percent) all recording robust gains. This pattern also reflectedthe distribution of the inflows of private capital.

In contrast, growth and capital inflows for most Central African economies registered below the regional average, save for Congo (Brazzaville) with growth of (9.1 percent), thanks to new oil that came on steam, thus making it the fastest growing economy in SSA in 2010. Though growth rates in several Southern African countries (Botswana, Malawi, Mozambique, and Zambia) exceeded 6 percent, slower growth in Angola, Southern Africa's largest economy (excluding South Africa) dampened growth for the sub-region. South Africa, the largest economy in the region, grew at a 2.8 percent pace in 2010 (Global Economic Prospects, 2011). This paper addresses the problem as towhy some SSA countries enjoy higher economic growth and attract more global private capital flows than others.

\subsection{Objectives of the paper}

The objectives of the are as follows: (1) to outline the sources and factors influencing global capital flows to SSA; (2) analyze economic strategies implemented by successful SSA countries to attract global capital flows; and (3) provide policy implications and recommendations for SSA policymakers to enhance their competitiveness in the global economy of the twenty-first century.

\section{Methodology}

This paper relies on the literature review of current relevant articles focusing on global private capital flows to developing countries in general and SSA in particular. Except where a source was needed specifically for its perspective on broad issues relating to capital flows to developing countries and SSA, the author screened papers by "global private capital flows to SSA" and by numerous variants of keywords, focusing specifically on SSA. Source papers included refereed research studies, empirical reports, and articles from professional journals. Since the literature relating to global private capital flows is voluminous, the author used several decision rules in choosing articles. First, because capital flows is changing fast in today's environment, the author used mostly sources published from 2000-2011, except where articles were needed specifically for their historical perspectives. Second, given the author's aim to provide a practical understanding of the main issues in global private capital flows to SSA, he included, in order of priority: refereed empirical research papers, reports, and other relevant literatures on current trends in global capital flow to SSA. To get some perspective on the current state of global private capital flow to developing countries and SSA, the author begins with a review of the current literature.

\section{Literature Review}

\subsection{Foreign Direct Investment}

Most empirical analyses focus on FDI. Recent surveys of the empirical literature by Chakrabaiti (2001) and Kamaly (2002) suggest that a few selected variables play a key role in a country's ability to attract FDI. The most important variables are the host country's growth prospects, the openness of the host market, and the institutional environment. In addition, a number of nontraditional variables, such as the quality of infrastructure, political stability, and the level of economic distortions, have also been found to affect FDI. Overall, the results of empirical analyses suggest that several broad categories of factors influence a country's attractiveness for FDI. 
These are its macroeconomic performance, the investment environment, infrastructure and resources, the quality of institutions, and global factors. In addition, recent research has shown that FDI tends to cluster in particular locations (Kamaly, 2002). More specifically, FDI flows depends on a country's past stock of FDI; that is, countries that have been successful in attracting FDI in the past are more likely to do so in the future (Goldberg and Kolstad, 1994).

Only a few empirical analyses focus on FDI to SSA. Asiedu (2002) found that a number of factors explain SSA's limited success in attracting FDI. SSA countries tend to be less open than other emerging markets; are perceived as very risky; and, despite absolute improvements in the policy environment, have lost ground relative to other regions. Rogoff and Reinhart (2003) argue that a high incidence of regional conflicts, high and volatile rates of inflation, and frequent currency crashes play an important role in explaining why SSA lags behind other regions in attracting FDI. Based on some SSA success stories, Basu and Srinivasan (2002) posit that political and macroeconomic stability, well-designed structural reforms, and natural resources contributed to an increase in FDI in these countries. For example, comparing South Africa with a group of similarly rated countries, Arvanities (2003) found that South Africa had lower rates of growth, was less open to trade, and lacks labor skills.

\subsection{Portfolio Inflows}

Unlike the voluminous literature on the determinants of FDI inflows, research on the determinants of portfolio inflows to emerging markets is more limited. Most of the empirical analyses focus on industrial countries, owing, in part, to data availability and the fact that portfolio flows, especially equity inflows, to emerging markets and developing countries began very recently, mostly in the late 1980s (Asiedu and Lien, 2004).

Early investigations of portfolio flows analyzed whether they were driven by push or pull factors. Based on quarterly portfolio data (both equity and debt) during 1989-93 for a panel of 13 middle-income countries, Fernandez-Arias (1996) found that the increase in capital inflows to most countries was driven largely by low returns in developed countries - that is by push factors. In a more comprehensive study, Chuhan and others (1998) analyzed monthly U.S. equity and bond flows to nine Latin American and nine Asian countries during 1988-92. They found that although global factors-U.S. interest rates and industrial production - are important, country-specific developments are equally important, particularly for Asia. They also reported that equity inflows are more sensitive than bond flows to global factors.

\subsection{Composition of Capital Flows}

The early empirical literature on the composition of flows has stressed regional differences. During the 1970s and 1980s, Latin America was often associated with short-term portfolio flows, while Asian countries attracted more FDI. Montiel and Reinhart (1999) showed that regional differences have diminished over time and that economic policies can influence the composition capital flows. They found that capital controls alter the composition, but not the volume, of capital flows and that sterilized intervention can affect both volume and composition. Using data from 25 transition countries, Garibaldi and others (2002) found that the determinants of FDI and portfolio flows are different. While FDI is well explained by economic fundamentals, a well-developed financial market infrastructure and property-rights indicators are the only robustly significant variables affecting portfolio investment. Carlson and Hernandez (2002) explored whether policies can alter the composition of capital inflows and if composition aggravates crisis. They found that, if the exchange rate is allowed to float, the share of short-term debt in total capital inflows increases. Capital account restrictions are associated with a higher share of FDI. Carlson and Hernandez also found that portfolio equity flows respond to policies in a similar way as FDI.

The above results already provide some indication as to what determines the composition of capital flows. So far, they suggest that some determinants of capital flows are specific to certain types of flows, whereas other determinants have a similar impact on FDI, bond, and equity flows. For example, more trade openness, more natural resources, and fewer restrictions on export receipts affect FDI inflows positively, but have little impact on portfolio flows. Therefore, it is expected that these variables also affect the share of FDI positively. Common determinants may be growth prospects and the quality of institutions, proxied by the rule of law. Higher exchange rate volatility may have opposite effects on FDI and portfolio flows (Ahmed et al, 2005).

\subsection{Determinants of Capital Inflows}

Based on the above literature review, the author identifies and describes the following indicators for the five broad categories of factors that influence capital flows. Their relevance and expected signs are as follows: (1) Macroeconomic performance: A rapidly growing economy is likely to offer higher future earnings and thus 
higher rate of return coupled with lower risk; (2) Quality of institutions: Theoretical and empirical findings suggest that good institutions help promote capital inflows (Wei and Wu 2001). A country that ranks higher in terms of law and order is expected to attract more capital inflows (Alfaro et al, 2003); (3) Investment environment: The openness of the economy, the degree of exchange rate and inflation volatility, and exchange controls are three key ingredients of the investment environment (Asiedu, 2002; Morisset, 2000).

(4) Financial development: The deeper a country's financial markets, the more capital flows the country attracts. In particular, well-developed financial markets appear to be a precondition for portfolio inflows (Garibaldi et al, 2002). For FDI, deeper financial markets may allow foreign firms to finance short-term and long-term transactions more easily and meet capital needs in the local market (Alfaro et al, 2003).

(5) Global factors: The principal global variables that influence capital inflows are international interest rates and business cycle developments in industrial countries (Calvo et al, 1993). Foreign investment decisions are determined in part by the opportunity costs of FDI. FDI or portfolio flows will be less attractive if international returns on investment rise. Real short-term and long-term U.S. interest rates are used as an indicator for global developments. International long-term interest rates matter for FDI because it, too, is long term. For portfolio flows, a large part of which is short-term, the money markets rate may play a larger role (Kamaly, 2002).

The findings suggest that some of the variables that matter for FDI also play an important role in attracting portfolio flows. Higher growth rates, better institutions, and lower international interest rates make the environment favorable to portfolio inflows. In the case of portfolio investments, short-term interest rates developments abroad appear to be the relevant measure for opportunity costs; long-term bond yield developments appear to be more important for FDI.

In line with previous findings, well-developed financial markets help increase a country's attractiveness for portfolio flows (Porte and Rey, 2000). Capital account restrictions in the form of multiple exchange rate practices tend to deter portfolio inflows. However, the impact of other capital account restrictions is inconclusive, which may reflect limitations associated with this measure, such as a failure to take partial liberalization into account (Miniane, 2004). What is most interesting is that the results also suggest that exchange rate volatility does not have a statistically significant effect on portfolio flows; in some cases, the coefficient is even positive, though not statistically significant. This finding supports the often heard view that some portfolio investors are comfortable with currency volatility because of an implied pick-up in yield caused by higher currency risk premium. In addition, portfolio investors may find it easier and less costly to hedge against currency risk than FDI investors because of the shorter investment horizon.

\subsection{FDI Flows to SSA}

There is little doubt that SSA economies have relied on FDI for too long. Relatively, far too little economic activity on the continent is carried out by SSA businesses and shockingly little trade occurs between SSA countries. Nevertheless, direct investment by non-SSA companies certainly can have a massive impact on local economies. Firstly, greenfield FDI-where new operations are set up rather than existing companies taken over-can create large numbers of new jobs. Secondly, the financial influx can build infrastructure, provide technological expertise and inject human capital, all of which can encourage associated SSA companies and operations to become more efficient. Finally, FDI can boost economic growth and generate more taxes, whether direct or indirect, to help fund national life, development and social welfare. However, FDI does not have a uniform positive impact on every sector and every country. Tax holidays, poor regulation and the displacement of local communities can all reduce the positive contribution that foreign companies make to domestic economies (Ford, 2011).

\subsection{Portfolio Equity Flows to SSA}

Portfolio equity flows to SSA rose by 10 percent in 2010, reaching $\$ 11 \mathrm{bn}$. The strong growth performance of SSA economies over the last decade (5 percent per year) coupled with increasing political stability and reforms that have lowered barriers to entry, have begun to place SSA countries on the radar screens of portfolio equity managers. This is evidenced in the recent establishment of a number of SSA-focused private equity funds. Not surprisingly, South Africa receives the largest share of such inflows. However, other economies, including Nigeria, with its fast growing economy and large population; Kenya, which is often viewed as the gateway to the $\$ 84 \mathrm{bn}$ East African economy, and Ghana, with its stable political environment and fast growing economy, are of particular interest (Global Economic Prospects, 2011).

South Africa also dominated bond flows to the region, accounting for almost all of the $\$ 4.7 \mathrm{bn}$ in regional bond sales during 2010. However, with an estimated \$93bn annual infrastructural deficit, and a funding gap of \$31bn, 
a number of countries in SSA (Ghana, Kenya, Tanzania, and Zambia) continue to express interest in tapping the Euro-bond market. In January 2011, Nigeria issued a \$500m debut Eurobond, which was oversubscribed. In March 2011, Zambia received a "B+" credit rating from international credit rating agencies. Several other countries are revamping their laws to tap into the nearly $\$ 1$ trillion Islamic financial market. Senegal has indicated that it plans to raise $\$ 200 \mathrm{~m}$ in Islamic financing in 2011. Increasingly, foreign investors are participating in local bond markets, notwithstanding the foreign exchange risk. Ghana's February 2011 auction of GHS $400 \mathrm{~m}(\$ 263 \mathrm{~m})$, in 3-year bonds attracted significant global interest and was oversubscribed by 88 percent. Kenyan auctioned a 9-year infrastructure bond worth 31.6bn shillings $(\$ 380 \mathrm{~m})$ in August 2010, and the country is likely to continue to tap the market in 2011. Indeed, local currency bond supply in SSA is estimated to have increased from $\$ 7 \mathrm{bn}$ in the 1990 s to almost $\$ 20 \mathrm{bn}$ by 2008 . Improving liquidity is also supporting the extension of the yield curve in a number of countries, with Nigeria offering 20 -year maturities and Kenya up to 30-year maturities (Global Economic Prospects, 2011).

\section{Theoretical Framework Analysis}

The starting point of much of the recent literature on determinants of capital flows has been an attempt to explain the Lucas Paradox, or why private capital doesn't seem to flow from rich to poor countries. Standard neoclassical theory predicts that capital should flow from capital-rich countries (with low marginal productivity of capital) to capital-scarce countries (with a high marginal product of capital). In practice however, the bulk of observed flows, particularly in the modern period, consists of flows among developed economies. Compared to the early $20^{\text {th }}$ century era of financial globalization, the current wave of capital flows is characterized by massive diversification of flows between high-income economies and a relative marginalization of less-developed economies (Obstfeld and Taylor, 2004; Schularick, 2006; Schularick and Steger, 2008).

Some authors posit that the paradox is due to country-specific fundamentals that tends to lower the marginal product of capital in developing countries, such as missing factors of production including human capital, poor economic policies, and poor institutions (Alfaro, Kelemi-Ozcan and Volosovych, 2005; Faria et al, 2006; Faria and Mauro, 2004; Schularick and Steger 2008). In this vein, a recent study shows that the extent of domestic financial market development and the quality of domestic financial institutions has played a significant role in attracting capital flows to emerging markets (International Monetary Fund, 2007). The second set of explanations centers around international capital market imperfections, such as asymmetric information, sovereign risk and capital controls. For example, Portes and Rey (2005) found that informational frictions, proxied by geographic distance, affect the amount and direction of capital flows, and Lane (2004) also found that credit market frictions are a determinant of debt flows in 1970-1995.

As mentioned earlier, few studies focus on the role played by the extent of domestic financial market development in attracting international capital flows. While the literature tends to link capital flows (financial globalization) to improvements in domestic financial systems (e.g. Chinn and Ito, 2005; Mishkin, 2006), in principle the direction of causality is not clear. Chinn and Ito (2005) find empirical evidence supporting the notion of a threshold effect: financial openness contributes to equity market development only when a threshold level of general development of legal systems and financial development is attained. However, although property rights and financial institutions could potentially affect capital flows differently, no study of the determinants of capital flows has empirically attempted to properly disentangle the effects of both.

Ju and Wei (2007) develop theoretical models showing that financial institutions and property rights institutions can have different effect on capital flows. Whereas an inefficient financial system can be bypassed by international capital flows, as they could come in the form of FDI instead of portfolio and debt flows, high expropriation risk cannot be bypassed. Conversely, the stronger domestic property rights, the more the country will benefit from international capital flows.

While it is easy to make a theoretical case for the positive impact of capital flows on growth, the empirical verification of this impact has proved much more challenging. Alternate explanations to this empirical puzzle have predicated the gains from capital flows on the threshold development of certain domestic institutions, and/or proposed that such flows generate certain indirect or collateral benefits even when their direct impact on growth is difficult to gauge. Klein (2005) found support for a model in which institutional quality intermediates the impact of capital account liberalization on growth by affecting the extent to which savings are protected from expropriation and the premium borrowers pay for funds from abroad. In countries with better institutions, capital account openness has a significant positive impact on growth. Bekaert, Harvey, and Lundblad (2005) found that the largest growth response to equity market liberalizations accrues to countries with better legal systems, above-average financial development, and better-quality institutions in terms of investors' protection and 
accounting standards. Using industry-level data, Prasad, Rajan, and Subramanian (2007) indicated that for countries that have above-medium levels of financial development, foreign capital aids the relative growth of those industries dependent on finance. But for countries below the medium for financial development, the effect of foreign capital flows is diametrically opposite. Using firm-level data, Alfaro and Charlton (2007) found a significant relationship between entrepreneurial activity and both de jure and de facto international capital integration. Their results suggest that foreign capital may improve access to capital either directly or through improved domestic financial intermediation.

Recent evidence, however, indicates that countries that grow more rapidly are those that rely less and not more on foreign capital, and in turn foreign capital tends to flow to countries that experience not high, but low productivity growth (Prasad, Rajan and Subramanian 2007; Gourinchas and Jeanne, 2007). One possible explanation for this puzzle is trade: fast-growing countries also are the ones that experienced a takeoff in their export sector (Gourinchas and Jeanne, 2007). If capital inflows lead to higher prices for non-traded goods owing to absorptive capacity constraints, and thus to overvaluation, they will have a negative impact on exports and hence growth (Kose et al, 2006; Prasad, Rajan, and Subramanian, 2007). Another explanation is that inflows from abroad that supplement domestic savings will have a limited impact in an economy where the binding constraint is the scarcity of viable investment opportunities (Rodrik and Subramanian, 2009).

\section{Findings}

\subsection{Policies to Attract Private Capital Inflows}

Given deteriorating public finances and the prospects of an anemic recovery in donor countries, economies in SSA are likely to have to rely increasingly on private financing. This section explores which structural, institutional, and policy pull factors have been important in attracting private capital inflows to top performing economies (Ghana, Nigeria, Botswana, South Africa, Zambia, Tanzania, etc.)in a SSA context.

Top performers were more integrated in the global economy with respect to financial and trade flows. Top performers had more open capital accounts and total gross private inflows were significantly higher. However, top performers also had higher financial outflows and trade shares. There were no significant differences in the composition of inflow (FDI, portfolio, and others) or in trade and current account balances as a percent of GDP.

Top performers had bigger and more developed financial sectors. Broad money was significantly higher relative to GDP in top-performing countries, while private sector credit was higher though not significant.

Top performers had higher measures of institutional quality. Top performers had better institutions as measured by the World Bank's governance indicators. The rule of law and regulatory quality were both highly significant, and control of corruption was marginally significant.

Top performers had higher levels of human capital. They had higher adult literacy rates and more internet access, indicating a greater ability to supply human capital complementary to foreign investment flows.

Top performers had better macroeconomic outcomes. They had higher investment and savings rates and enjoyed significantly higher real growth.

\section{Discussion and Analysis}

\subsection{Capital Inflows during the Financial Boom}

In the period of the recently-ended boom in global financial markets, inflows of private capital became the most important source of external finance for SSA. The increase in private capital flows to the region was in line with that in other regions and all low-income countries (Dorsey et al., 2008; World Bank, 2007). On average, in the period between 2001 and 2007 total gross inflows to the region increased by 32 percent annually-the rate accelerating to 44 percent after 2005. Private capital flows to SSA have risen almost six-fold since 2000, from about $\$ 15 \mathrm{bn}$ to about $\$ 84 \mathrm{bn}$ in 2007 . Recorded private capital outflows are on the whole much smaller than inflows, so that in 2007 net capital flows to SSA amounted to about \$76bn. As of 2007, private capital flows represented 10 percent of the region's GDP, about twice the volume of ODA (about $\$ 40 \mathrm{bn}$ ). A Confluence of factors was responsible for the surge in private capital. A significantly improved macroeconomic performance across much of the continent, and for some countries the implementation of the Multilateral Debt Reduction Initiative (MDRI), coincided with increases in global liquidity and higher oil and commodity prices (Delechat et al., 2009).

\subsection{Determinants of Private Capital Flows to SSA}

Capital flows to SSA, particularly portfolio flows, have been concentrated in a relatively small number of countries with relatively sophisticated financial markets. In these countries capital has flown into equities where 
the stock market was sufficiently developed (e.g. Kenya and Nigeria), government bonds in countries that had sovereign issues (Botswana and Ghana), and short-term government securities (Uganda, Tanzania, and Zambia) when few other investment vehicles open to non-residents were available. The availability of investment instruments appears to have dominated the existence of capital controls. For example, in Tanzania legal loopholes allowed international investors to purchase significant amounts of government securities although in principles foreigners were not allowed to hold government debt (International Monetary Fund, 2008).

\subsection{Impact of Capital Flows on SSA Growth Rates}

One approach to gauging the likely impact on capital inflows on growth is to look at the various channels described in the literature on financial globalization and growth. Three broad channels are identified as linking capital inflows and growth:

Overvaluation: To the extent that capital inflows cause currency appreciation they hurt exports and thus dampens growth. This channel is well-documented in Rodrick (2007), but also discussed in Prasad et al (2007).

Savings and Investment: Where foreign capital supplements domestic savings it fosters growth. However, this would only be true for economies where the main constraint on growth is a lack of savings. Where the main hindrance to economic growth is the scarcity of viable investment opportunities additional foreign capital will only add to domestic distortions (Gourinchas and Jeanne, 2007; Rodrick and Subramanian, 2009).

Institutional development: A number of studies argue that capital inflows carry indirect (collateral) benefits for recipient countries via the development of domestic institutions (Becker et al, 2007; Kose et al, 2006), or more particularly financial sector institutions (Mishkin, 2006).

The findings indicate that in most instances capital flows are not significantly correlated with the channel variable mentioned above. Except when capital flows are scaled to the size of the recipient country's population - both savings and investment are positively and significantly related to capital in this instance. This implies that, for SSA countries, the impact of private capital flows on growth could be partly intermediated through the impact of net capital flows on domestic savings and investment. Another implication would also be that SSA economies are not necessarily investment-constrained.

\subsection{Macroeconomic Management Challenges}

The increasing reliance on private external financing poses challenges for macroeconomic management, given the relative size and volatility of these flows. First, although net private capital flows to SSA constitute only about one tenth of total net private flows to emerging and developing countries, the inflows are large relative to the economic size of the recipient countries. Second, the more volatile flows have the potential to cause considerable difficulties in monetary management in SSA, given shallow financial markets. For instance, in proportion to reserve money, nonresident holdings of government securities have swung from almost nothing to more than 40 percent in some countries.

So what can SSA countries do to manage large inflows should they resume? The IMF has recently developed a framework to help countries manage large capital inflows. The main message is that, there is no substitute for implementing appropriate macroeconomic policies, countries can choose from a menu of policy options to respond to capital inflows. For example, tightening fiscal policy can reduce inflows that may be attracted to high yields resulting from high fiscal deficits. However, in some cases, it may also be appropriate to consider taxes, certain prudential measures, and capital controls (Sayeh, 2011).

\subsection{The Role of Abundant Global Liquidity}

Abundant global liquidity is in part responsible for the surge of private capital flows to SSA. But investors were also attracted by SSA's recent solid macroeconomic performance, more stable political situations, and high expected returns given surging commodity prices. Their interest was reflected in improved investment ratings, the renewed ability of some countries to tap international capital markets (Gabon, Ghana, and Seychelles have recently issued bonds internationally), and the growing number of private investment funds dedicated to SSA (Daelechat et al, 2008).

Also rising portfolio flows into a small group of SSA countries with more developed financial markets suggest that these countries are transitioning to emerging market status. Indeed, many SSA countries compared favorably with East Asian countries in the 1980s. However, the scale of the policy challenges and the environment for emerging markets in SSA are dramatically different (Daelechat et al, 2008).

\subsection{Country-specific Policy Responses}

SSA policy makers face particular constraints in responding to the policy challenges of capital inflows. In most 
cases, the lack of timely and accurate data has made it difficult for them to design an appropriate and effective policy response.Hence, the first challenge is to adapt monetary and exchange rate policies to the persistence of capital inflows. Uganda, Tanzania, and Zambia tried sterilized interventions - to counter undesirable exchange rate movements by altering their debt composition without affecting their monetary base. Sterilized interventions could help countries preserve exchange rate and monetary stability in the short term while allowing them to build up official reserves as insurance against sudden reversals.

Similarly, capital account policies and government debt issuance strategies can help alleviate concerns about "hot" short term portfolio inflows. For instance, Ghana was successful in limiting inflows of more volatile short term capital through its design of capital controls, similar to those used by Chile in the 1990s. In Uganda and Zambia, the lengthening of maturities of government debt instruments made it possible to deepen the long end of the market and incidentally broaden the local investor base.

\subsection{SSA Long-Term Growth Prospects}

What thenare SSA's long-term prospects? The Africa Progress Penal Report in 2011 is optimistic. According to the report, while growth trajectories will continue to differ substantially (especially between oil exporters and diversified economies), SSA's collective GDP is estimated to reach $\$ 2.6$ trillion in 2020, and consumer spending $\$ 1.4$ trillion. Based on this positive outlook, more and more SSA countries are now regarded as promising investment destinations, including Botswana, Cape Verde, Ghana, Kenya, Seychelles, South Africa, Tanzania, Uganda, and Zambia. However, in order to make the most of the SSA's enormous potential, the report concludes that SSA's leaders, with the help of their international partners, need to accelerate economic diversification and structural transformation. Without such transformation, growth will remain inequitable, jobless, volatile, and largely inadequate for achieving the MDGs by 2015 (Versi, 2011). Therefore, the drive for economic transformation should be the focus for governments working with, and supporting, a revitalized private sector (Amoako, 2011).

\subsection{The Role of Financial Market Development in Capital Inflows to SSA}

Beside South Africa, other countries such as Botswana, Ghana, Kenya, Mauritius, Nigeria, Seychelles, Tanzania, and Zambia also boast relatively developed financial markets. Some have already tapped, or intend to tap global capital markets to fund ambitious infrastructural projects. Private capital inflows are now rising - after falling to $\$ 1.5 \mathrm{bn}$ in 2010 (from \$2.6bn in 2008) according to the Emerging Markets Private Equity Association. The Carlyle Group, the US private equity firm, is reportedly launching an Africa-focused \$5oom fund. Meanwhile, FDI in SSA has totaled almost $\$ 320$ bn over 2006-2010, up from $\$ 117 \mathrm{bn}$ in the preceding five-year period. Encouragingly, non-resource sectors have drawn fresh investments to a wide range of countries. While minerals, particularly hydrocarbons, should attract large chunks of FDI in the medium term, other sectors with growth potential are renewable energy, financial services, ITC, and agro-production ( Siddiqi, June 2011). Capital flows are determined by a variety of macroeconomic and institutional factors and the relative risks associated with these investments (Bhattacharya, Montiel, and Sharma, 1997).

The rise in portfolio flows to the SSA was particularly rapid. Although almost 90 percent of these sent to South Africa, they were also on the rise in a small group of other countries - notably Ghana, Kenya, Tanzania, Uganda, and Zambia - in response to improved risk ratings and attractive yields (Daelechat et al, 2008). However, the problem with portfolio capital in financial market is that they are normally targeted at large and growing markets. This makes further argument for de-fragmentation of SSA stock exchanges. Attracting portfolio capital flows into stock markets goes hand in hand with opening up markets to foreign participants help to increase trading and liquidity of markets. Increasingly SSA markets are opening up to foreign participation with little or no ceilings on foreign ownership of shares. A few markets still have some foreign participation restrictions. For example, foreign ownership of shares cannot exceed 40 percent in stock markets in Kenya and Zimbabwe and 74 percent in Ghana (Yartey and Adjasi, 2007).

\subsection{Rebound in capital flows}

Thanks to recovery in the global economy, as well as an increasing recognition by investors of the opportunities presented in a rapidly growing developing region, net private capital flows to SSA increased from $\$ 35.8 \mathrm{bn}$ in 2009 to an estimated $\$ 41.1 \mathrm{bn}$ in 2010 and are projected to rise to $\$ 48.6 \mathrm{bn}$ in 2011 . The leading destination of FDI inflows, in value terms, is to the capital intensive mining sector. Indeed, higher commodity prices and the global competition to secure supplies of commodities have spurred investments globally in the natural resource sector. SSA, a region with a high proportion of known mineral resources with great potential for further development is benefitting from this trend. This has been facilitated by improvements to regulatory regimes in some countries. Capital raisings by SSA resource companies are reported to have increased by 240 percent 
compared to 2009. Much exploratory activity has been ongoing in several countries during 2011, with new discoveries and production coming on stream (Global Economic Prospects, 2011).

\subsection{Regional Heterogeneity of SSA Growth Rates}

Though overall growth in SSA remains strong, there is significant heterogeneity across sub-regions. An encouraging aspect of the trend rise in SSA growth rates has been the extent to which almost all countries have seen significant improvements in their growth. Strong SSA growth does not reflect extremely high growth rates by one or two economies, but solid growth in several countries with the highest growth rates comparable to those of other fast growing developing economies. Only two economies grew by less than 2 percent in 2010, while the bulk registered solid growth rates of between 2 and 6 percent, 30 percent of countries in the region enjoyed real GDP growth rates of more than 6 percent. Across sub-regions, growth was strongest in West Africa (6.5 percent) powered by Nigeria's robust growth (7.9 percent) and supported by Ghana's 7.7 percent gains in the year. GDP growth in East Africa was almost as strong, with Ethiopia (7 percent), Rwanda (7.5 percent), Tanzania (7 percent) and Kenya (5.6 percent) all recording robust gains.

In contrast, growth for most Central African economies registered below the regional average, save for Congo (Brazzaville) with growth of (9.1 percent), thanks to new oil that came on steam, thus making it the fastest growing economy in SSA in 2010. Though growth rates in several Southern African countries (Botswana, Malawi, Mozambique, and Zambia) exceeded 6 percent, slower growth in Angola, Southern Africa's largest economy (excluding South Africa) dampened growth for the sub-region. South Africa, the largest economy in the region, grew at a 2.8 percent pace in 2010 (Global Economic Prospects, 2011).

\subsection{The Strength the Financial Sectors}

Financial sectors in many SSA economies remain shallow and vulnerable. Banking sectors serve only a small proportion of the population, nonbank financial institutions are weak, and supervisory capacity is low. Non-performing loans in the banking sector have increased in a number of countries in the region, constraining the availability of credit and with a potential to affect public sector balance sheets (Ramachandran, Gelb, and Shah, 2009). The exceptionally rapid expansion of bank credit to the private sector in the mid-2000s - upward of 40 percent per annum in many countries - stretched banks' assessment capacity and regulators' supervisory competence, increased exposure to asset and capital market volatility, and shifted the balance of final demand in the economy in some countries. It also underpinned a diversification in the institutional structure of financial sectors that substantially complicated the task of regulators.

Looking ahead, the urgent need is for regulatory capacity to catch up with the increasing depth and breadth of financial sector activity, including through cross-border institutions. Stress testing can highlight the vulnerabilities that these new interconnections bring with them. Contingency plans should be regularly updated in the light of the clear international financial fragilities that persist. But there is also a need for closer monitoring of the direct macroeconomic consequences of credit and money growth, including their implications for asset prices and spending volatility (International Monetary Fund, 2010).

\subsection{Benefits of Increase External Financial Integration}

The costs and benefits of external financial integration remain finely balanced. Increased access to foreign capital can in theory boost economic growth, reduce macroeconomic volatility, and contribute to domestic financial development. At the same time, however, financial opening has also been associated with more frequent and severe economic crises. Crucial factors in determining whether capital flows will aid or hinder development are the adequacy of institutional and policy frameworks.

For many of the SSA's low-income countries and fragile states currently marginalized from international capital markets, the challenge will be to develop the domestic investment opportunities that can attract foreign capital. Experience within SSA suggests that the reforms needed to unlock an economy's productive potential—such as promoting trade and financial sector development, encouraging domestic savings and investment, and raising standard of governance and strengthening institutions - are also helpful in attracting private capital flows and making these flows more productive. Given the time taken to implement such reforms, these countries should carefully monitor the implications and effects of financial opening. There is reason to be more confident of increases in FDI, which can result in the transfer not just resources but also know-how, and is generally beneficial even for countries with relatively weak economic fundamentals (International Monetary Fund, 2010).

\section{Implications for Public Policies in SSA Economies}

The key policy implications for countries attempting to attract FDI are to create a better investment climate by (a) improving access to adequate infrastructural and institutional facilities; (b) providing a stable, consistent, and 
transparent legal and regulatory framework and decreasing red tape; and (c) engaging in international governance arrangements. More importantly, SSA countries should identify and develop those national competitive advantages that are likely to be of particular interest to foreign investors. In this context, countries should promote local skills development in order to broaden the opportunities for entrepreneurial activity. SSA economies also should strengthen their investment-promotion activities by establishing a broad-reaching agency that can list and market investment opportunities as well as provide information about doing business in the country. Countries should focus not only on policies to attract FDI, however, but also on the policies that are necessary for FDI to generate a positive development impact in the recipient country (Global Development Finance 2006).

\subsection{Policy Challenges of Inflows}

The acceleration of private capital flows into SSA creates opportunities for the region, especially given that aid flows have remained unchanged in recent years. Private capital gives countries an alternative source of financing for infrastructure and other investments, thus stimulating growth and helping countries make progress toward achieving the Millennium Development Goals (Montiel and Reinhart, 1999).

However, this implies that significant private capital inflows could increase macroeconomic volatility and build financial sector vulnerabilities, leading over time to real exchange rate appreciation and a loss of competitiveness. In SSA, private capital flows occur in the context of large export receipts stemming from higher commodity and oil prices (Cameroon, Ghana, Nigeria, Senegal, and Zambia) and scaled-up official inflows (Uganda and Tanzania), compounding the challenges for policy makers (Daelechat et al, 2008).

\subsection{TheFuture Agenda for SSA Economies}

Private capital flows are poised to replace official aid as the most important source of external finance for SSA. This is a welcome development, but it puts a premium on sound macroeconomic management, transparent capital account policies, and financial sector reforms to ensure that countries use the inflows productively while avoiding macroeconomic instability and sudden reversals.

In the long run, the growth benefits of capital inflows depend on better domestic institutions and deeper and strong financial markets. Countries in SSA have already made significant progress toward these goals, and their efforts should continue to be rewarded (Delechat, et al, 2008).

All this means that policy makers in SSA will need to pay increasing attention to efforts to attract private capital to their countries. This research indicates that one of the most important things policy makers can do to attract private capital is to strength domestic capital markets. Deep and well-functioning money, foreign exchange, equity and (where relevant) derivative markets are key to attracting private capital. Governments in SSA economies would be well-advised to redouble their efforts to develop and strengthen these markets, to put their countries in a position to attract private capital in the future. At the same time, an important lesson of the recent global financial crisis should be to put in place strong monitoring, regulatory and supervisory frameworks, to avoid a buildup of balance-sheet vulnerabilities (Delechat et al, 2009).

Finally, policymakers will need to consider these and other tools as capital flow to the region resume. The experience of emerging markets in recent crises has refocused attention on the possible role of financial disincentives and other instruments to discourage potentially volatile flows. There may, for example, be a case for tightening prudential requirements or imposing penalties in response to temporary surges in capital flows if: (1) an economy is operating near potential (ruling out lower interest rates), political considerations and implementation lags limit the scope for fiscal consolidation, (3) foreign reserves are adequate, and (4) the exchange rate is already overvalued such that further appreciation would damage competitiveness. Where increases in inflows prove to be persistent, however, the economy will eventually need to adjust to a permanently higher exchange rate (Ostry et al, 2010).

\section{Policy Recommendations}

\subsection{The Need for Institutional Infrastructure}

There is the need for a well structured and clear rule of law, within an efficient judicial system, which allows for contract repudiation and expropriation risk in this regard. This helps in making optimal decisions, increasing access to external finance and resulting in productive investment and eventually higher firm growth (La Porta, Lopez-de-Silanes and Shleifer, 2003).

Moreover, regular disclosure, transparency and enforcement form an integral part of regulation and supervision in the financial market. Important disclosure requirements include relevant information with regards to 
transactions, accounting and the identity of ultimate beneficial owners. They must be nonetheless simple and supportive of the legal and accounting framework (Friedman and Grose, 2006). Similarly enforcement procedures need to be long, cumbersome and expensive. Enforcement essentially requires compliance and the ability to prosecute. The presence of a securities regulator is important in this regard to ensure enforcement. Such enforcement can also be complimented by effective private laws on contracts and dispute resolutions (Lopez-de-Silanes, 2004). The presence of strong corporate governance mechanisms also help boost investor confidence in regulatory issues.

Similarly, strict ethical and conduct of business rules should be developed for members of SSA stock exchanges. Rules must follow international best practices but at the same time reflect local structures and needs. Emerging SSA markets should also implement rules that are necessary rather than what would be nice (Friedman and Grose, 2006). In SSA though, there are laws and rules for regulation and supervision. The real challenge is the shortage of experienced supervisors and the absence of a strong tradition favoring compliance with the rules and discouraging regulatory forbearance (Vittas, 1998).

\subsection{Attract Capital Inflow and Encourage More Foreign Participation in Stock Markets}

Private capital flows-FDI, remittances, portfolio investment are important for stock market development. Even though capital flows to SSA have been increasing recently, they are still at very low levels. In particular, portfolio investment accounts for a minor share of capital flows to SSA with a meager of 0.5 percent of the total capital flows to SSA (excluding South Africa). On the other hand, portfolio flows dominate the total capital flows to South Africa increasing liquidity on the Johannesburg Stock Exchange (Yartey and Adjasi, 2007).

This means that SSA countries need to do more to attract capital flows especially portfolio flows and encourage more foreign participation in their stock markets. Sustained economic growth, quality public institutions and infrastructure, trade liberalization, and efficient capital markets are important for attracting capital flows (Asiedu, 2006). An enabling business climate with low costs of doing business, property rights, effective regulations and legal institutions, and some capital account liberalization are also crucial.

\subsection{Impact of Capital Account Restrictions on Capital Inflows}

Lastly, capital account restrictions still hold in a number of SSA countries. Such restrictions also limit the capabilities of exchanges to explore cross-border investments. There is the fear that capital account liberalization for these countries could also expose such economies to potential huge capital flights and financial crisis. However, it has been argued that such problems depend on the nature of capital that comes in (Henry, 2000). Private loan based capital flows could cause crises if there is bad news and creditors rush in to obtain their funds. Equity or bond based capital flows however have the risk shared, with high payouts during good times and little or nothing during bad times. Therefore, lifting capital account restrictions to attract portfolio investment would benefit SSA's stock markets tremendously. Of course capital account liberalization should be preceded by trade liberalization and domestic financial liberalization to minimize financial market risks (Yartey, 2005).

\section{Concluding Remarkings}

Private capital flows to SSA rose sharply during the recent expansion, though they failed to keep pace with the boom experienced in some other emerging and developing regions. However, the reduction caused by the global financial crisis was correspondingly more modest. This partly reflects the composition of these flows and the relatively greater importance in SSA of FDI, which proved more resilient than other forms of private capital.

The boom in private capital flows bypassed over one-third of the countries in SSA, and much of the region is still not integrated into the international capital markets and dependent on official external financing.

For the region as a whole, when measured over a full economic cycle, financial flows have typically been a greater source of volatility than trade flows. However, during the current crisis, for many countries, movements in the terms of trade outweighed the reversal in private capital flows. For oil producers, deterioration in the terms of trade was exacerbated by the reduced availability of private external financing. However, remittance flows to the region have held up surprisingly well.

Among countries that attracted significant capital inflows before the crisis, better macroeconomic management when funds were flowing in was associated with superior performance when the global financial crisis hit and private capital flows diminished. Specifically, countries that had shown more fiscal restraint when inflows were surging experienced less deterioration in economic growth after the crisis (International Monetary Fund, 2010).

Although portfolio and other flows had healthy growth, they still comprised only 38 percent of total inflows in 2007, and substantially less if South Africa - by far the region's largest recipient of portfolio inflows - is excluded. The nature of the region's access to international capital markets became progressively more diversified as it broadens out beyond FDI and traditional bank lending. Sovereign borrowers in Ghana, Gabon, 
and Seychelles tapped international bond markets during 2006-2007, and a growing number of countries secured sovereign credit ratings in anticipation of eventual issues.

The appropriate response to large capital inflows will depend on country-specific circumstances, including the nature of the inflows, the stage of the business cycle, and the strength of public finances and foreign reserves. However, experience elsewhere suggests that (1)maintaining fiscal restraint rather than allowing procyclical increases in public spending during period of large inflows can help limit currency appreciation and reduce the risk of a hard landing when the flows reverse; (2) resisting nominal exchange rate appreciation tends to be ineffective if there is a persistent surge in capital inflows and can lead to excessive increases in domestic demand if the monetary impact of intervention cannot be neutralized; and (3) tightening capital controls does not seem to deliver better outcomes except perhaps where an economy is operating at near full potential, the level of reserve is adequate, the exchange rate is not undervalued, and flows are likely to be transitory.

In sum, countries in SSA that are moving toward frontier or emerging market status face additional challenges. Insulating an economy from the volatility of cross-border financial flows, including more footloose flows such as portfolio and other short-term investments, becomes progressively more difficult in the face of growing merchandise trade and the development of domestic financial sectors. Macroeconomic policy needs to focus particularly on the risk of overheating, loss of competitiveness, and increased vulnerability to crises in the face of larger and potentially volatile movements in flows to these countries (International Monetary Fund, 2010).

\section{References}

Ahmed et al (2005). The composition of capital flows: Is South Africa different? IMF Working Paper WP/05/40 (Washington, D. C: International Monetary Fund).

Al-Khalil, M. (2003). Essays on the determinants of international portfolio investments. Swedish School of Economics and Business Administration WP No. 114 (Helsinki, Finland: Swedish School of Economics and Business Administration).

Alfaro, L. and Charlton, A. (2007). International financial integration and entrepreneurial firm activity. NBER Working Paper No. 13118 (Cambridge, Mass.: National Bureau of Economic Research).

Alfaro et al. (2005). Capital flows in a globalized world: The role of policies and institution. NBER Working Paper No. 11696 (Cambridge, Mass.: National Bureau of Economic Research).

Alfaro et al. (2003). Why doesn't capital flow from rich to poor countries? An empirical investigation. Working Paper 040 (Boston, Mass.: Harvard Business School).

Amoako, K. (2011). Transforming Africa: Start now, we can’t wait. African Business, (July) 377, 24-27.

Anonymous (2011). Opening a new chapter on Africa. African Business, (May) 375, $22-26$.

Arvanitis, E. (2003). Determinants of foreign direct investment in South Africa. Selected Issues Paper, IMF Country Report 03/18 (Washington, D.C: International Monetary Fund).

Asiedu, E. and Lien, D. (2004). Capital controls and foreign direct investment. World Development, 32 (March), 479-90.

Asiedu, E. (2002). on the determinants of foreign direct investment to developing countries: Is Africa different? World Development, 30 (January), 107-19.

Asiedu, E. (2006). Foreign direct investment in Africa: The role of natural resources, market size, government policy, institutional and political instability. The World Economy, 21, 63-77.

Basu, A. and Srinivasan, K. (2002). Foreign direct investment in Africa: Some case studies. IMF Working Paper 02/61 (Washington, D. C: International Monetary Fund).

Bekaert, G., Campbell, R. H., and Lundbald, C. (2005). Does financial liberalization spur growth? Journal of Financial Economics, 77, 66-72.

Carlson, M. and Hernandez, L. (2002). Determinants and repercussions of the composition of capital inflows. IMF Working Paper 02/86 (Washington, D. C: International Monetary Fund).

Calvo et al. (1993). Capital inflows and real exchange rate appreciation in Latin America: The role of external factors. IMF Staff Paper, 40 (March), 108-51.

Chakrabarti, A. (2001). The determinants of foreign direct investment: Sensitivity analyses of cross-country regression. Kyklos, 54, 89-114.

Chinn, M.D., and Ito, H. (2005). A new measure of financial openness. [Online] Available: www.ssc.wisc.edu/\%Emchinn/research.html.

Chuhan et al. (1998). Equity and bond flows to Latin America and Asia: The role of global and country factors. Journal of Development Economics, 55 (April), 439-63.

Delechat et al. (2009). Sub-Saharan Africa's integration in the global financial markets. IMF Working Paper WP/09/114 (Washington, D. C: International Monetary Fund). 
Delechat et al. (2008). Sub-Saharan Africa: Private capital fueling growth. IMF Survey Magazine, (May 22) 1-5. Dorsey et al. (2008). The landscape of capital flows to low-income countries. IMF Working Paper 08/51 (Washington, D. C: International Monetary Fund).

Faria, A., Minnoni, M., and Zaklan, A. (2006). The external financing of emerging marketing countries: Evidence from two waves of financial globalization. IMF Working Paper 06/205 (Washington, D.C: International Monetary Fund).

Faria, A. and Mauro, P. (2004). Institutions and the external capital structure of countries. IMF Working Paper 04/236 (Washington, D. C: International Monetary Fund).

Fernandez-Arias, E. (1996). The new wave of private capital inflows: Push or Pull? Journal of Development Economics, 48 (March), 382-418.

Ford, N. ( 2011). FDI trickle to turn into a flood. African Business, (April) 374, 52-56.

Friedman, B. F. and Grose, C. (2006). Promoting access to primary equity markets: A legal and regulatory approach. Policy Research Working Paper No. 3892 (Washington, D. C: World Bank).

Garibaldi et al. (2002). What moves capital to transition economies. IMF Working Paper 02/64 (Washington, D. C: International Monetary Fund).

Goldberg, L. and Kolstad, C. (1994). Foreign direct investment, exchange rate variability, and demand uncertainty. NBER Working Paper No. 4815 (Cambridge, Mass.: National Bureau of Economic Research).

Gourinchas, P.O., and Jeanne, O. (2007). Capital flows to developing countries: The allocation puzzle. NBER Working Paper No. 13602 (Cambridge, Mass.: National Bureau of Economic Research).

Gordon, J. and Gupta, P. (2003). Portfolio flows into India: Do domestic fundamentals matters? IMF Working Paper 03/20 (Washington, D.C: International Monetary Fund).

Griffin et al. (2002). Daily cross-border equity flows: Pushed or pulled? NBER WP No. 9000 (June) (Boston, Mass.: National Bureau of Economic Research).

Henry, B. P. (2000). Do stock market liberalizations cause investment booms? Journal of Financial Economics, $58,301-334$.

IMF (2010). Regional economic outlook: sub-Saharan Africa back to high growth? World Economic and Financial Surveys (Washington, D. C: International Monetary Fund).

IMF (2008). Regional Economic Outlook: Sub-Saharan Africa (Washington, D. C: International Monetary Fund).

IMF (2007). Global Financial Stability Report (Washington, D.C: International Monetary Fund).

IMF (2007). Reaping the benefits of financial globalization. IMF Research Department discussion paper (Washington, D. C: International Monetary Fund).

Ju, J. and Wei, S.J. (2007). Domestic institutions and the bypass effect of financial globalization. NBER Working Paper No. 13148 (Cambridge, Mass.: National Bureau of Economic Research).

Kamaly, A. (2002). Behind the surge in FDI to developing countries in the 1990s: An empirical investigation. (unpublished; College Park, MD: University of Maryland).

Klein, M.W. (2005). Capital account liberalization, institutional quality and economic growth: Theory and evidence. NBER Working Paper No. 11112 (Cambridge, Mass.: National Bureau of Economic Research).

Kose et al. (2009). Thresholds in the process of international financial integration. NBER Working Paper No. 14916 (Cambridge, Mass.: National Bureau of Economic Research).

Kose et al. (2006). Financial globalization: A reappraisal. IMF Working Paper 06/189 (Washington, D.C: International Monetary Fund).

La Porta, R et al. (2003). What works in securities laws? NBER Working Paper No. 9882 (Boston: National Bureau of Economic Research).

Lane, P.R. (2004). Empirical perspectives on long-term external debt. Topics in Macroeconomics, 4, 56-61.

Levy et al. (2007). The cyclical nature of North-South FDI flows. Journal of International Money and Finance, $26,104-130$.

Lopez-de-Silanes, F. (2004). A survey of security laws and enforcement. Policy Research Working Paper No. 3405 (Washington, D. C: World Bank).

Mishkin, F.S. (2006). The next great globalization: How disadvantaged nations can harness their financial systems on get rich. (Princeton, NJ: Princeton University Press).

Mlachila, M. and Takebe, M. (2011). FDI from BRICS to LICs: Emerging growth driver? IMF Working Paper WP/11/178 (Washington, D. C: International Monetary Fund).

Montiel, P. and Reinhart, C. M. (1999). Do capital controls and macroeconomic policies influence the volume 
and composition of capital flows? Evidence from the 1990s. Journal of International Money and Finance, 18 (August), 619-35.

Morisset, J. (2000). Foreign direct investment in Africa: Policies also matter. Policy Research Working Paper No. 2481 (Washington, D. C: World Bank and the International Finance Corporation).

Obstfeld, M. (2009). International finance and growth in developing countries: What have we learned? IMF Staff Paper No. 56 (Washington, D. C: International Monetary Fund).

Obstfeld, M. and Taylor, A. M. (2004). Global capital markets: Integration, crisis, and growth. (Cambridge, England: Cambridge University Press).

Ostry et al. (2010). Capital inflows: The role of controls. IMF Staff Position Note SPN/10/04 (Washington, D. C: International Monetary Fund).

Portes, R. and Rey, H. (2005). The determinants of cross-border equity flows. Journal of International Economics, 64, 269-296.

Portes, R. and Rey, H. (2000). The determinants of cross-border equity flows. Discussion Paper No. 446 (London: Center for Economic Performance).

Prasad et al. (2007). Foreign capital and economic growth. Brookings Papers on Economic Activity: 1 Brookings.

Ramachandran et al. (2009). Africa's private sector: What's wrong with the business environment and what to do about it. (Washington, D. C: Center for Global Development).

Richards, A. (2002). Big fish in small ponds: The momentum investing and price impact of foreign investors in Asian emerging equity markets. Research Discussion Papers 2004-05 (Sydney: Reserve Bank of Australia).

Rodrik, D. and Subramanian, A. (2009). Why did financial globalization disappoint?IMF Staff Paper, 56, (Washington, D.C: International Monetary Fund).

Rodrik, D. and Subramanian, A. (2008). Why did financial globalization disappoint? Working Paper 2008-0143 (Cambridge, Mass.: Weatherhead Center for International Affairs, Harvard University).

Rodrik, D. (2007). The real exchange rate and economic growth: Theory and evidence. Harvard University Working Paper No. 1032 (Cambridge, Mass.: Harvard University).

Rogoff, K. and Reinhart, C. (2003). FDI to Africa: The role of price stability and currency instability. IMF Working Paper 03/10 (Washington, D. C: International Monetary Fund).

Sayeh, A. (2011). Capital flows to the final frontier. IMFdirect, (May 24) 1-5.

Schularick, M. (2006). A tale of two globalizations: Capital flows from rich to poor in two eras of global finance. International Journal Finance and Economics, 11, 339-354.

Schularick, M. and Steger, T. (2008). The lucas paradox and the quality of institutions: Then and now. Berlin University Working Paper No. 2008/3 (Berlin, Germany: Berlin University).

Siddiqi, M. (2011). A compelling case for investing in Africa. African Business, (June) 376, 40-41.

Siddiqi, M. (2011). Turning the resource curse into a blessing. African Business, (April) 374, 44-45.

Versi, A. (2011). Africa progress panel report. African Business, (July) 377, 18-20.

Vittas, D. (1998). Institutions investors and securities markets: Which comes first? World Bank Working Paper 2032 (Washington, D. C: World Bank).

Wei, S. and Wu, Y. (2001). Negative alchemy? Corruption, composition of capital flows, and currency crises. NBER Working Paper No. 8187 (Cambridge, Mass.: National Bureau of Economic Research).

World Bank (2011). Sub-Saharan Africa. Global Economic Prospects: Regional Annex (Washington, D. C: World Bank).

World Bank (2009). Global Development Finance: Charting a Global Recovery (Washington, D. C: World Bank).

World Bank (2008). Global Development Finance: The globalization of corporation finance in developing countries (Washington, D.C: World Bank).

World Bank (2006). The development potential of surging capital flows. Global Development Finance (Washington, D. C: World Bank).

Yartey, C. A, and Adjasi, C. K. (2007). Stock market development in sub-Saharan Africa: Critical issues and challenges. IMF Working Paper WP/07/209 (Washington, D. C: International Monetary Fund).

Yartey, C. A. (2005). Stock market development, corporate finance and economic growth in Africa. PhD Thesis (Cambridge: Faculty of Economic). 